\title{
RNA-binding protein conserved in both microtubule and microfilament-based RNA localization
}

\section{Leora Havin, ${ }^{1,3}$ Anna Git, ${ }^{1-3}$ Zichrini Elisha, $^{1}$ Froma Oberman, ${ }^{1}$ Karina Yaniv, ${ }^{1}$ Sigal Pressman Schwart, ${ }^{1}$ Nancy Standart, ${ }^{2}$ and Joel K. Yisraed $i^{1,4}$}

\begin{abstract}
${ }^{1}$ Department of A natomy and Cell Biology, Hebrew University M edical School, Jerusalem 91120, Israel; ${ }^{2}$ Department of Biochemistry, University of Cambridge, Old Addenbrookes Site, Cambridge CB2 1GA, UK
\end{abstract}

V g1 mRNA translocation to the vegetal cortex of Xenopus oocytes requires intact microtubules, and a 3' UTR cis-acting element (termed VLE), which also mediates sequence-specific binding of several proteins. One protein, the 69-kD Vgl RBP, associates Vg1 RNA to microtubules in vitro. Here we show that Vgl RBP-binding sites correlate with vegetal local ization. Purification and cloning of Vgl RBP revealed five RNA-binding motifs: four KH and one RRM domains. Surprisingly, Vgl RBP is highly homologous to the zipcode binding protein implicated in the microfilament-mediated localization of $\beta$ actin mRNA in fibroblasts. These data support Vgl RBP's direct role in vegetal localization and suggest the existence of a general, evolutionarily conserved mecha nism for mRNA targeting

Received January 21, 1998; revised version accepted M arch 25, 1998

Intracellular RNA localization leads to asymmetric protein synthesis, a necessary step in the process of pattern formation during early embryogenesis in many species (for review, see St. Johnston 1995; Gavis 1997). In Xenopus oocytes, morphological and molecular differences between the animal and vegetal hemispheres help define the primary axis around which subsequent development proceeds. Two temporally distinct pathways have been identified for vegetal RN A localization. The early pathway facilitates localization of several RN As found to be I ocalized during stages I-II of oogenesis (Xcat-2, XIsirts, Xwnt-11), appears to be microtubule-independent, and is correlated with the migration of the mitochondrial cloud to a small region at the vegetal pole (Kloc et al. 1993; Mosquera et al. 1993; Forristall et al. 1995; Kloc and Etkin 1995; Zhou and King 1996a). The second pathway

[Key Words: RNA Iocalization; Vgl RBP; Xenopus; oocytes; microtubules; $\mathrm{KH}$ domain]

${ }^{3}$ These authors contributed equally to this work.

${ }^{4}$ Corresponding author.

E-MAIL yisraeli@yam-suff.cc.huji.ac.il; FAX 972-2-675745. occurs during late stage III-early stage IV, requires intact microtubules, and targets RN A to a tight shell along the entire vegetal cortex (Melton 1987; Yisraeli and M elton 1988; Yisraeli et al. 1990). So far, only one mRN A, Vgl, is known to localize via the second pathway in vivo, although Xcat-2 RNA can employ this pathway when injected into stage III oocytes (Zhou and King 1996b). VegT/Xombi/Apod/Brat RNA is also localized to the vegetal cortex in a manner resembling the second pathway, but it is not yet known whether this local ization requires intact microtubules; furthermore, it is released from the cortex in stage $\mathrm{V} / \mathrm{VI}$ oocytes, significantly earlier than is Vgl RN A (Lustig et al. 1996; Stennard et al. 1996; Zhang and King 1996). Cis-acting el ements mediating one or the other pathway have been mapped, by deletion analysis, to extensive regions of the $3^{\prime}$ UTRs (Mowry and Melton 1992; Zhou and King 1996a,b; Gautreau et al. 1997). Trans-acting factors that bind these regions and may provide a link between the RNA and components of the cytoskeleton have been characterized only preliminarily, and the connection between these interactons and local ization is just beginning to be defined (Schwartz et al. 1992; M owry 1996; Deshler et al. 1997).

Vgl RN A-binding protein (RBP) is a 69-kD oocyte protein that binds specifically to the vegetal localization element (VLE) of Vgl RNA (Schwartz et al. 1992). Because it is enriched in the microtubule fraction of oocytes and mediates the association of VLE sequences to microtubules in vitro (Elisha et al. 1995), Vgl RBP is a good candidate for a trans-acting factor involved in Vgl RNA local ization. In this paper we have mapped the Vgl RBP-binding sites in the V gl VLE, and, using confocal microscopy to visualize injected wild-type and mutant VLEs in the same oocyte, we observe a di rect correlation between the presence of two Vgl RBP-binding sites and vegetal local ization. The unexpected finding that the microtubule-associated protein Vgl RBP is highly homologous to the microfilament-binding zipcode biding protein (ZBP-1) involved in $\beta$-actin mRN A localization suggests that microtubule and microfilament-based systems of local ization may be more related than originally anticipated.

\section{Results and Discussion}

To determine whether Vgl RBP binding to the VLE correlates with vegetal localization, we first used UV crosslinking to precisely map cis-acting Vgl RBP-binding sites in the 366-nucleotide-long VLE. Initial mapping experiments indicated that two nonoverlapping regi ons at each end of the VLE can both bind Vgl RBP (Fig. 1a). We chose to pinpoint the Vgl RBP-binding sites using a linker-scan (LS) approach, which allowed us to compare the effects of relatively minor sequence changes (unaltered in length by deletions) to wild-type sequences. Twentynucleotide segments of VLE sequence were sequentially replaced with a 20-nucl eotide linker sequence that does 
a

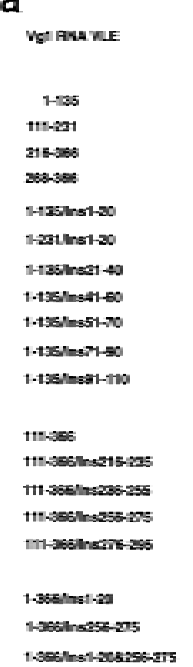

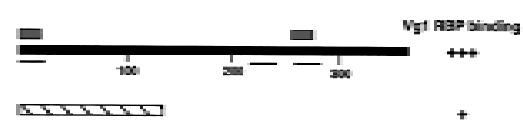
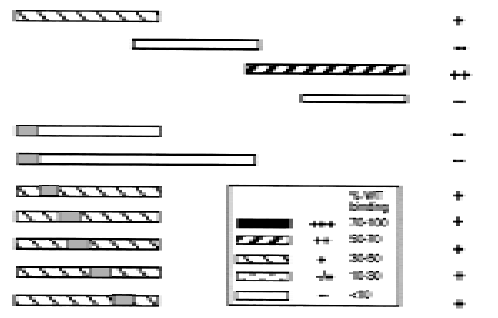

कारुकात

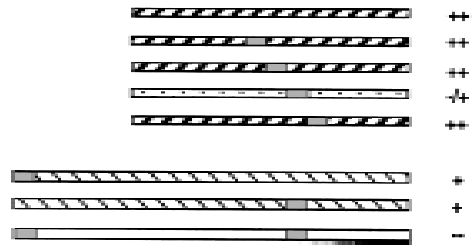

b

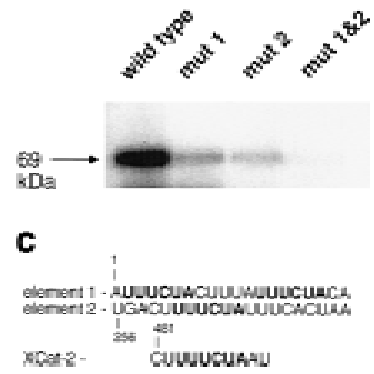

Figure 1. Cis-acting binding el ements in the VLE and their role in localization. (a) The ability of different fragments of the VLE, as well as of the LS, substituted VLE fragments, to bind Vgl RBP is schematically represented. The coordinates of the fragments and the substitution used for each binding assay (with the first nucleotide of the VLE numbered 1 and the substitution indicated as Ins) are listed at the left. The two regions identified as being important for Vgl RBP binding are indicated by the boxes at the top. Domains protected by oocyte proteins from RN ase degradation, mapped and label ed by M owry (1996) as C, A/B, and D, respectively, are shown as lines beneath the full-length VLE. The degree of binding is indicated in the inset. (b) A representative UV cross-linking experiment (summarized in a) is shown for wild-type VLE, 1-366/ins1-20 (mut 1), 1366/ins256-275 (mut 2), and 1-366/ins1-20\& 256-275 (mut 1\&2) RN As. (c) The nucleotide sequences of the first and second binding elements in the VLE are compared with a sequence from the $3^{\prime}$ UTR of Xcat-2 RN A from the region mapped as containing a late pathway localization element (Zhou and King 1996b). The hexanucleotide UUUCUA present in all these sequences is indicated in boldface type.

not bind Vg1 RBP (Figs. 1 and 2; data not shown). In each of the regions that binds Vgl RBP independently, one 20-nucleotide el ement was found to be essential for Vgl RBP binding. Although substitution of each of these elements individual ly (leaving the other intact) in the context of the full-length VLE partially reduces Vgl RBP binding, loss of both el ements abolishes binding almost completely (Fig. 1b). Thus, Vgl RBP appears to bind independently at two distinct sites in the VLE. We note that a hexanucl eotide repetitive sequence, UUUCUA, is found in two copies in the first element, once in the second element, and nowhere else in Vgl RN A (Fig. 1c; see below).

Local ization of VLE RN As with substitutions in either one or both of the Vgl RBP-binding elements was compared with the local ization of wild-type VLE using the oocyte culture system described previously (Yisraeli and Melton 1988). Microinjected VLE RNA with both sites substituted was homogeneously distributed throughout the oocyte after 5 days in culture, in contrast to wildtype VLE, which shows clearly defined vegetal localization (Fig. 2a). The effects of substituting either site al one were assayed by simul taneously injecting wild-type VLE RNA, labeled with digoxygenin-UTP, and substituted VLE RNA, label ed with fluorescein-UTP; their localization was visualized by confocal microscopy using rhoda- mine and Cy-5-labeled antibodies, re spectively (Fig. 2b). Substitution of either site alone significantly impairs localization, as indicated by the presence of the substituted RN A throughout most of the oocyte (red channel). Significantly, a low level of cortical Iocalization of the singly substituted VLEs can be detected colocal izing (in yellow) with the wild-type VLE RNA (green channel) (Fig. 2b), but this colocalization was not detected with the double substitutions (data not shown). This technique allows us to quantify the degree of partial local ization of the substituted RNAs with respect to the internal wild-type VLE controls. For both singly substituted RNAs, we estimate this degree of partial local ization to be on the order of $20 \%$.

Initial characterization of the VLE performed by Mowry and Melton (1992) showed that deletions removing either $5^{\prime}$ or $3^{\prime}$ sequences from the VLE significantly impair local ization; these deletions included, respectively, either the upstream or downstream elements we have pinpointed here. More recently, Mowry (1996) identified, by RNase footprinting, three distinct regions of the VLE protected by Xenopus oocyte proteins; two of these regions fall precisely at the sites identified here for Vgl RBP binding (see Fig. 1a). As mentioned above, a 6-nucl eotide sequence present in two copies in the first el ement is al so present in one copy in the second element (Fig. 1c). This sequence is also present in the region of Xcat-2 RN A, which is important for its localization via the late pathway (Fig. 1c) (Zhou and King 1996b). In UV cross-linking assays, Vgl RBP binds Xcat-2 RNA (Z. Elisha, pers. comm.). An oocyte protein, termed Vera, reported to be associated with the ER and of a slightly larger size than Vgl RBP, has been recently described as also binding the VLE (Deshler et al. 1997). Del etion of two 9-nucl eotide repeats from the first 20 nucleotides of the VLE (containing the hexanucleotide sequence mentioned above) al so impairs localization significantly, as well as reducing Vera binding. (These investigators also found that additional combinations of deletions can affect localization and protein binding.) A very recent set of experiments by Gautreau et al . (1997) further emphasizes the importance of the Vg1 RBP-binding sites we have mapped here. They identified two subelements, at the $5^{\prime}$ and $3^{\prime}$ ends of the VLE, whose del etion severely impai rs local ization (the $5^{\prime}$ subelement is 1-135 and contains the first Vgl RBP-binding site, and the $3^{\prime}$ subel ement is 201-340 and contains the second Vgl RBP-binding site; see Fig. 1, $a$ and c). Each of these subelements is incapable, on its own, of vegetal local iza- 
a
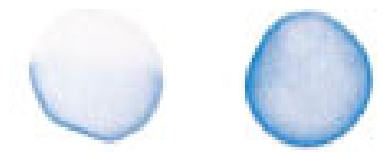

wild type

b
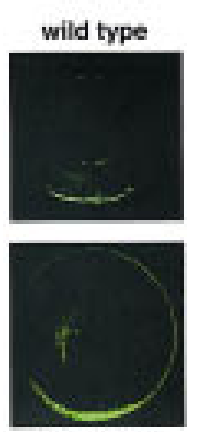

wild type mut 182
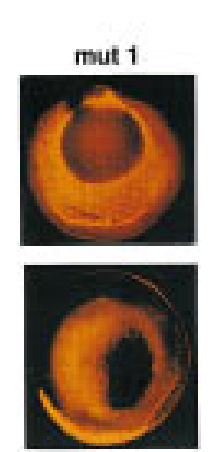

mut 2
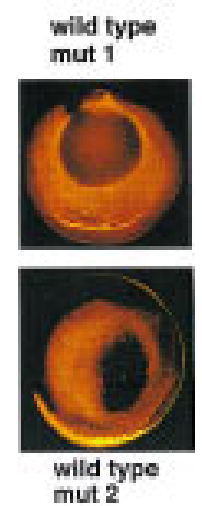

Figure 2. Localization of wild-type and mutant VLEs in oocytes. (a) The distribution of wild-type VLE RNA or double substituted VLE mut 1\&2 RN A (1-366/ins1-20\&256-275, see Fig. la for map) following injection into late stage III oocytes. mut 1\&2 RNA appears to be fairly uniformly distributed throughout the oocyte; wild-type VLE shows strong cortical Iocalization to the vegetal hemisphere al one. (b) Confocal micrographs of late stage III oocytes coinjected with wild-type VLE RN A (green channel) and either mut 1 RN A (1-366/ins1-20, see Fig. 1a) or mut 2 RNA (1-366/ins256-275) (red channel). Although the majority of both the mutant RN As is not localized, some colocal ization with the wild-type VLE RN A (yellow, third column) is observable.

tion, but a duplicated 5' subelement localizes well. This first subelement contains two copies of the hexanucleotide repeat, and mutations in this repeat eliminate vegetal localization. These results complement those presented here, in which we have preserved the basic structure and length of the VLE. Taken together, these data strongly suggest that the two Vgl RBP-binding sites represent a cis-acting element required for localization via the late pathway and that cooperative $\mathrm{Vgl}$ RBP binding is required for proper localization.

T o clone Vgl RBP, we first purified it from a Xenopus oocyte S100 lysate by sequential column chromatography. As shown in Figure $3 a$, Vgl RBP, assayed by UV cross-linking, el utes off a heparin-Sepharose column in the range of 250-500 mM KCl. Then, these fractions were passed over an RNA affinity column, consisting of in vitro-transcribed VLE RN A attached to CN Br-activated Sepharose (Kaminski et al. 1995). Here, Vgl RBP activity, which elutes from this col umn between 500 and $700 \mathrm{~mm}$ $\mathrm{KCl}$, coincides with a principal silver-stained band migrating at $69 \mathrm{kD}$ (Fig. 3b). The purified protein does not bind VLE sequences with both binding el ements substituted, indicating that it has the same RNA-binding specificity as the oocyte extract protein (data not shown). Microsequencing of the gel-purified polypeptide generated five peptide sequences of 9-15 residues each. Subsequent RT-PCR of total Xenopus oocyte RNA using degenerate primers made to two "back-translated" pep-

tides (40 and 41; see M aterials and M ethods) yielded a product that encompassed the sequence of a third peptide (35). Screening of a Xenopus oocyte cDN A library with this PCR fragment resulted in a 2.4-kb cDN A, containing an ORF of 594 amino acids. All five peptides obtained from the purified Vgl RBP were found in the conceptually translated cDN A protein sequence (see Fig. 4). By N orthern blot analysis, Vgl RBP mRN A appears to be $\sim 2.8-3.0 \mathrm{~kb}$ long, implying that this clone is missing some noncoding region sequences (data not shown).

Database and literature searches with the Vgl RBP peptides and, subsequently, the complete ORF, revealed a striking sequence conservation with an RBP implicated in mRN A localization in polarized somatic cells. Localization of $\beta$-actin mRNA to the leading edge of chick fibroblasts requires the presence of conserved elements in its 3' UTR, included in a 54-nucleotide sequence termed the zipcode (Kislauskis et al. 1993, 1994). The 68-kD ZBP-1 that binds to wild-type, but not to mutant zipcode sequences inactive in RNA localization, recently has been cloned (Ross et al. 1997). Vgl RBP and ZBP-1 share $78 \%$ identical amino acids (Fig. 4). The searches also reveal ed that a human protein of $\sim 65 \mathrm{kD}$, of unknown function, called KOC [KH-domain-containing protein overexpressed in cancer (M ueller-Pillasch et al. 1997)] is a very close relative of the local ization el ementbinding proteins. Alignment of all three proteins, shown
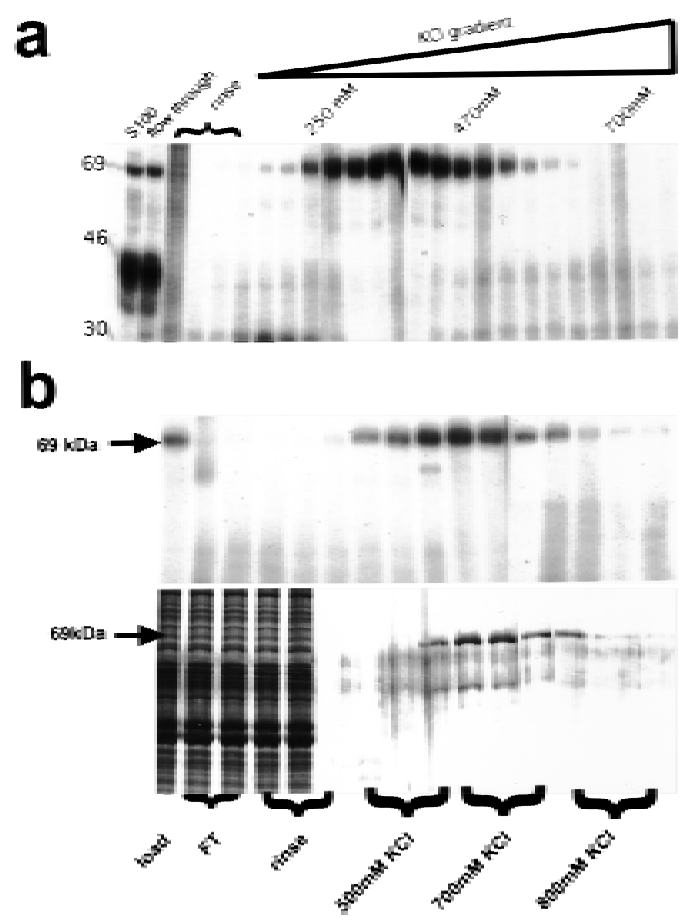

Figure 3. Biochemical purification Vgl RBP. (a) Fractions of the heparin-Sepharose column were assayed for Vgl RBP crosslinking activity. $\mathrm{KCl}$ concentrations (as determined by conductivity) of selected fractions are indicated. (b) Equivalent fractions of the RNA affinity column were assayed for Vgl RBP cross-linking activity (autoradiograph, top) and presence of protein (silver-stained gel, bottom). (Arrows) The location of Vgl RBP. 


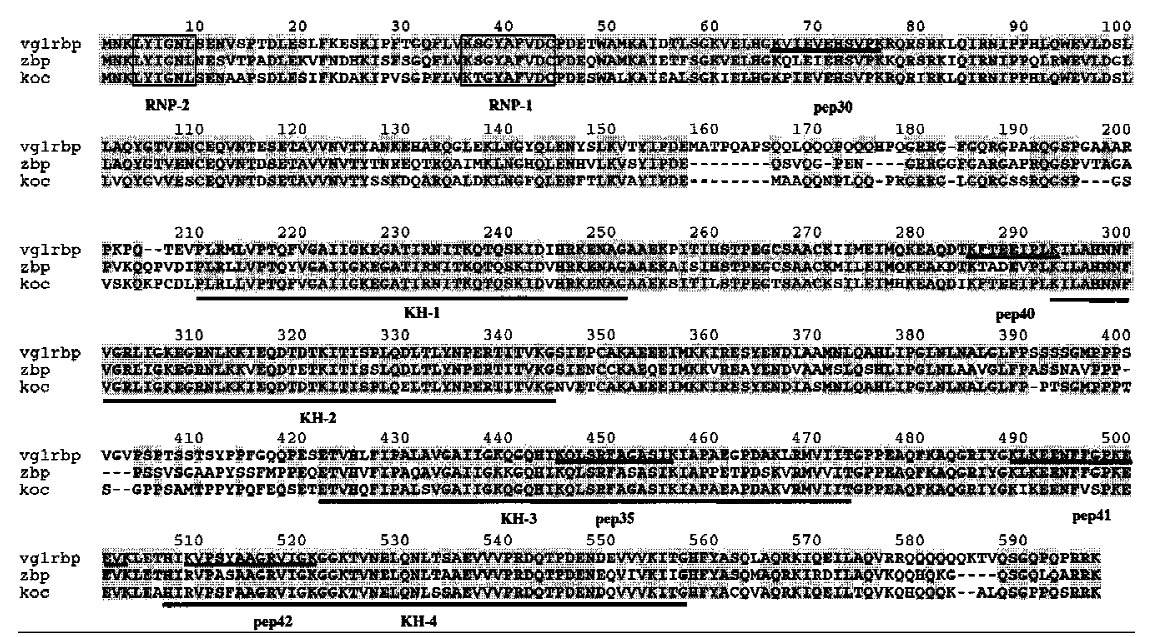

Figure 4. Vgl RBP protein sequence and its homology to ZBP-1 and KOC. The protein sequence for Vgl RBP is shown with the four KH (underlined) and one RRM (boxed) domains indicated. The five peptides that were obtained from the microsequencing of the purified Vgl RBP are underlined and labeled. ZBP-1 and KOC sequences are also shown, aligned to Vgl RBP, and identical amino acids are shaded. Percent identities/ homologies between the proteins are Vgl RBP/ZBP-1, 78\%/84\%; Vgl RBP/KOC, 83\%/ 87\%; ZBP-1/KOC, 76\%/80\%.

in Figure 4, indicates the high sequence conservation between Vgl RBP, ZBP-1, and KOC, which extends throughout their length. A prominent feature of all these polypeptides is their multiple predicted RNA-binding motifs, including one RN A recognition motif (RRM) domain and four tandem $\mathrm{KH}$ domains. The RRM, characterized by its RNP2 and RNP1 motifs, and the KH (hnRNP K homology) domain are responsible for the RNA-binding ability of a variety of snRNA, pre-mRNA, mRN A, and rRN A-binding proteins, including some that play an important role in early development (Siomi and Dreyfuss 1997). The RRM and KH domains are the most highly conserved regions of the three proteins. We note that a REV-like nuclear export sequence is also present and conserved in all three proteins (325-333 in Vgl RBP), but the functional importance, if any, of this motif is not clear. Our database searches failed to identify any obvious homologs of Vgl RBP in yeast, Drosophila, or Caenorhabditis elegans. On the other hand, we did find other vertebrate counterparts as partial EST clones in mouse (accession nos. aa073514 and aa117282) and zebrafish (aa495472).

Two independent lines of evidence suggest that the cloned gene is indeed Vgl RBP. First, the in vitro translation product made from the cloned gene is the same size as Vgl RBP in S100 extracts or purified by RNA affinity chromatography; in vitro-translated ZBP-1 comigrates with this band as well (Fig. 5a). Second, to address the question of whether the cloned gene encodes the binding activity defined in S100 extracts as Vgl RBP, antisense oligodeoxynucleoti des directed against coding sequences were injected into stage III oocytes. The ability of the oligonucleotides, following overnight incubation, to cause a specific loss of binding activity as a result of RN ase H-directed degradation of Vgl RBP mRNA was monitored by extracting protein and then by performing
UV cross-linking (Fig. 5b). Although none of the oligonucleotides causes a loss of Vgl RBP-binding activity when injected singly, a combination of two oligonucl eotides directs a clear drop in binding activity $(70 \%$ loss of control activity). This effect is very specific, as neither the sense oligonucleotide nor another combination of two antisense oligonucleotides influences Vgl RBP binding. Northern blot analysis of RNAs extracted in parallel from the injected oocytes, probed with a Vgl RBP DNA probe, shows precisely the same effect (data not shown). These results strongly suggest that the cloned gene encodes Vgl RBP.

The identification of $\mathrm{Vgl}$ RBP, shown here to mediate Vgl mRNA localization in Xenopus oocytes, as a close homolog of ZBP-1, a protein implicated in targeting $\beta$-actin mRNA in fibroblasts, is startling. It clearly suggests that this specific $3^{\prime}$ UTR-RBP is a common component in local ization pathways hitherto considered to be individual for mRN A and cell type, and raises several interesting questions. Despite the high degree of sequence similarity, significant functional differences exist between $\mathrm{Vgl}$ RBP and ZBP-1. The zi pcode motif that ZBP-1 binds includes a 6-nucleotide tandem repeat, ACACCC, which, when mutated, abrogates ZBP-1 binding (Kislauskis et al. 1993, 1994; Ross et al. 1997). The Vgl RBP-binding sites described here contain a different hexanucleotide repeat, UUUCUA, and are AU rich (see a

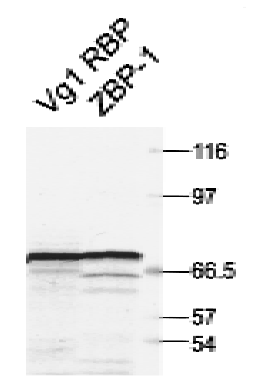

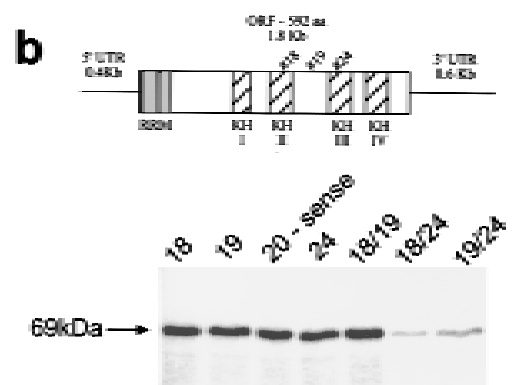

Figure 5. The cloned gene encodes Vgl RBP. (a) In vitro translation of Vgl RBP and ZBP-1 RNA. Both Vgl RBP and ZBP-1 translation products migrate close to $69 \mathrm{kD}$, according to the molecular mass markers (right). (b) UV cross-linking of S100 extracts from oocytes injected with the indicated oligonucleotides was performed. Using a Phosphorlmager to quantify the band intensities, we observed a $70 \%$ reduction in cross-linking activity (as compared to the control sense oligonucleotide 20) when oligonucleotides 18 and 24 are injected simultaneously, and a 50\% reduction when 19 and 24 are injected together. The third pair of oligonucleotides (18 and 19) had no effect on Vgl RBP-binding activity. The schematic drawing indicates the position of the oligonucleotides relative to the RNA-binding domains. 
Fig. 1c). The source of the different binding specificities of these proteins remains to be determined; certainly, as in the case of the fragile X FMR-1 gene, single-aminoacid substitutions in a $\mathrm{KH}$ domain can have profound affects (Siomi et al. 1994). An additional intriguing difference between the proteins lies in their cytoskeletal associations. $\beta$-Actin mRN A localization requires intact microfilaments (and not microtubules), and ZBP-1 coelutes from the RNA affinity column with other proteins including actin (Sundell and Singer 1991; Ross et al. 1997). Vgl RBP, however, associates with microtubules, both in vivo and in vitro, and can mediate the specific association of Vgl RNA to microtubules (Elisha et al. 1995). Furthermore, Vgl mRN A local ization requires intact microtubules in oocytes (Yisraeli et al. 1990). Importantly, localized $\beta$-actin mRN A in neurons appears to be complexed in large granules that are associated with microtubules rather than microfilaments (Bassell et al. 1998). Interestingly, several reports have suggested that microtubule- and microfilament-based localization mechanisms may be capable of interacting. For example, in squid axons, vesicles can move al ong either microtubules or microfilaments (Kuznetsov et al. 1992). In Drosophila oocytes, oskar mRN A localization to the posterior pole, which is sensitive to microtubule inhibitors and is mediated by Staufen protein (which can bind to microtubules), is disrupted by mutants in microfilament-binding cytoplasmic tropomyosin II (Erdelyi et al. 1995). In fact, microtubule-interacting sites and actinbinding domains may be topologically very similar, as suggested by a comparison of kinesin and myosin 3-D structures (Woehlke et al. 1997) and by the observation that in yeast, a kinesin-related protein can suppress some aspects of a myosin mutant phenotype (Lillie and Brown 1992). The presence of a highly conserved protein involved in the movement of both microtubule- and microfilament-based localized mRNAs suggests that the mechanism for RNA localization may be a very fundamental one that has been adapted by different cells for specific needs. It will be interesting to see what provides the cytoskel etal specificity for Vgl RBP and ZBP-1 and how additional, cell-specific proteins might mediate these interactions.

\section{Materials and methods}

\section{UV cross-linking}

For the LS and antisense experiments, UV cross-linking was performed using either 3 or $4 \mu \mathrm{g}$ of an oocyte S100 extract, respectively, as described previously (Elisha et al. 1995). UV cross-linking was al so used to assay for the presence of $\mathrm{Vg} 1 \mathrm{RBP}$ activity in the column fractions; following normalization of the salt concentrations (as measured by conductivity), equivalent aliquots of each fraction were tested. Full-length VLE RNA was used as a radioactive probe for the column and antisense assays. Templates to synthesize the probes for the LS analysis were constructed by PCR (Schwartz 1996), with the 5' primer containing a T3 RNA polymerase promoter and the linker, which replaced successive 20-nucl eotide segments of the VLE, consisting of the sequence GGGAACAAAAGCTTGCATGC. Substitutions were verified by sequencing. Probes for the LS analysis were synthesized in the presence of cap analog to prevent increased degradation as a result of the absence of polylinker sequence at the 5' end of the RNA (Schwartz 1996). Although bromo-UTP was used initially for synthesizing probes for the LS analysis, unsubstituted UTP was found to give identical results and used for subsequent experiments.
In the LS and antisense experiments, binding was quantitated using a Phosphorlmager, relative to internal controls.

Oocyte injections

Late stage III oocytes were injected with 1 ng of RNA (localization experiments) or oligodeoxynucleotides (antisense experiments) in $10 \mathrm{nl}$ of water. For localization experiments, oocytes were cultured for 5 days, as described (Yisraeli and Melton 1988). For the whole mount immunohistochemical visualization of RNA, exogenous digoxygenin-labeled RNA was detected using al kal ine phosphatase-conjugated anti-di goxygenin antibody and BM -Purpl e substrate (Boehringer M annheim). The coinjection experiments (performed with wild-type oocytes to allow for orientation) were visualized by confocal microscopy: Wild-type VLE RNA, labeled with digoxygenin-UTP, was detected by a rhodamine-labeled anti-digoxygenin antibody (green channel), and the substituted VLE, labeled with fluorescein-UTP, was detected by a mouse anti-fluorescein first antibody and a donkey Cy5 anti-mouse second antibody (red channel). No fluorescence was detected with the fluorescein-UTP-labeled RNA alone, and autofluorescence of the yolk was not detectable under the conditions used (data not shown). In Figure 2, the degree of partial localization of the mutant RNA, relative to the wild-type RNA, was determined by calculating the fraction of all the mutant RNA fluorescent signal that was localized to the cortex and comparing that to the fraction of all the wild-type RNA that was localized to the cortex.

Antisense oligodeoxynucl eotides consisted of the following sequences: (18) 5'-AAGTCCTGTAGTGGAGATAT; (19) 5'-ACTCCAACAGAAGGTGGTGG; and (24) 5'-TGCTTTCCAATAATCGCTCC. The sense oligodeoxynucleotide control (20) was the complementary sequence to number 18. All of the oligonucleotides were synthesized with the first four and last four nucleotides consisting of phosphorothioate links, to minimize degradation. When combinations of oligonucl eotides were injected, $0.5 \mathrm{ng}$ of each was used. Oocytes injected with oligonucleotides were incubated overnight at $19^{\circ} \mathrm{C}$ in $1 \times$ modified Barth's sal ine, and S100 protein extracts were prepared the following morning. Oocyte equivalents (1.2) of S100 extract $(\sim 3 \mu \mathrm{g})$ were used for UV cross-linking.

Purification and cloning of $\mathrm{Vgl}$ RBP

S100 oocyte extract (200 mg) was applied to a heparin-Sepharose column and eluted with a salt gradient. The fractions containing the 69-kD Vgl RBP-binding activity were pooled and concentrated using a Centricon filter. Six micrograms of the concentrated protein was loaded onto a CN Br-activated Sepharose column bound with $300 \mu \mathrm{g}$ of VLE RNA synthesized in vitro (Kaminski et al. 1995). After al lowing the sample to flow through the column, the column was washed with $100 \mathrm{~mm} \mathrm{KCl}$ and eluted with a salt gradient of $250 \mathrm{~mm}-1 \mathrm{M} \mathrm{KCl}$. UV cross-linking was performed on aliquots from representative fractions. Pooled fractions containing Vgl RBP were el ectrophoresed on a preparative gel. The Coomassie blue-stained Vg1 RBP band (of the same size) was excised from the gel, degraded with the endoprotease LysC, and the peptide products were then eluted and subjected to HPLC. Five clearly separated peaks were microsequenced by Edman degradation (see Fig. 3).

One microgram of total Xenopus-mixed oocyte RNA was reverse transcribed into single-stranded CDNA using the First Strand CDN A Synthesis Kit (Boehringer Mannheim) and random primers. An aliquot of the RT reaction was amplified by cloned Pfu DN A polymerase (Stratagene) with degenerate oligonucleotides (5'-AARTTYACTGARGARATHCC-3' based on peptide 40 KFTEEIPLK and 5'-CCRAARAARTTYTCYTCYTT3 ' based on peptide 41 KLKEEN FFGPKEEVK). The 600-bp PCR product was gel-purified and, following verification by automated sequencing, labeled by random priming. Screening of a Xenopus oocyte CDN A library in Bluescript pBRN 3 (generous gift of Nigel Garrett and John Gurdon, Wellcome/CRC Institute, Cambridge, UK) resulted in five clones that represented two allelic varients of Vgl RBP ( $97 \%$ identical). In this work we used a full-length clone of allele D, containing an ORF of 594 amino acids. The first AUG encountered in this CDNA was predicted to serve as the initiator codon due to the 4 in-frame stop codons in the unusually long 378-nucleotides 5' UTR.

In vitro translation

In vitro-transcribed capped mRN As of $100 \mathrm{ng}$ (Vg1-RBP) or $400 \mathrm{ng}$ (ZBP-1) were translated in $10 \mu \mathrm{l}$ of the reticulocyte cell-free lysate (Promega) in the presence of $\left.{ }^{35} \mathrm{~S}\right] \mathrm{M}$ et, and labeled products were separated by $15 \%$ SDS-PAGE. Loading volumes were adjusted to give similar intensity of products, to compensate for the lower efficiency of translation of ZBP-1 mRNA compared to that encoding Vgl RBP. 


\section{Acknowledgments}

We thank M. Tarshish for hel $p$ and expertise in confocal microscopy; R. Honikman for hel $p$ in finding conditions for the double labeling experiments; I. Marianovsky for excellent technical assistance with the heparin-Sepharose chromatography; N. Garret and J. Gurdon for the Xenopus oocyte CDN A library; R. Singer for the ZBP-1 clone; and Z. Paroush, H. Cedar, and D. St. Johnston for critical reading of the manuscript. This work was funded in part by the UK-Israel Science and Technology Research Fund (N.S. and J.K.Y.), the Israel Science Foundation (J.K.Y.), and the Israel Cancer Research Fund (J.K.Y). A.G. is the recipient of an Overseas Research Students Award.

The publication costs of this article were defrayed in part by payment of page charges. This article must therefore be hereby marked "advertisement" in accordance with 18 USC section 1734 solely to indicate this fact.

\section{Note added in proof}

Two genes highly related to Vgl RBP have appeared in GenBank while this paper was in press. B23 (accession no. AF042353) is a transcriptional activator of the TFIII $\alpha$ gene in stage I Xenopus oocytes and is identical to an allelic variant of Vgl RBP isolated during this cloning process (see Materials and M ethods). Vera (accession no. AF055923) is a Vgl RBP that has been implicated in Vgl RNA localization. It appears to be identical to Vgl RBP, al though its recognition site is reported to be different than that of Vgl RBP (Deshler et al. 1998, Curr. Biol. 8: 489-496). The functional significance of these proteins remains to be determined.

\section{References}

Bassell, G.J., H. Zhang, A.L. Byrd, A.M . Femino, R.H. Singer, K.L. Taneja, L.M. Lifshitz, I.M. Herman, and K.S. Kosik. 1998. Sorting of $\beta$-actin mRNA and protein to neurites and growth cones in culture. J. Neurosci. 18: 251-265.

Deshler, J.O., M .I. Highett, and B.J. Schnapp. 1997. Local ization of Xenopus Vg1 mRNA by Vera protein and the endoplasmic reticulum. Science 276: 1128-1131.

Elisha, Z., L. Havin, I. Ringel, and J.K. Yisraeli. 1995. Vg1 RNA binding protein mediates the association of Vgl RNA with microtubules in Xenopus oocytes. EMBO J. 14: 5109-5114.

Erdelyi, M., A.M. Michon, A. Guichet, J.B. Glotzer, and A. Ephrussi. 1995. Requirement for Drosophila cytoplasmic tropomyosin in oskar mRN A localization. Nature 377: 524-527.

Forristall, C., M. Pondel, L. Chen, and M.L. King. 1995. Patterns of Iocalization and cytoskeletal association of two vegetally localized RN As, Vg1 and Xcat-2. Development 121: 201-208.

Gautreau, D., C.A. Cote, and K.L.M owry. 1997. Two copies of a subelement from the Vgl RN A localization sequence are sufficient to direct vegetal localization in Xenopus oocytes. Development 124: 5013-5020.

Gavis, E.R. 1997. Expeditions to the pole: RNA localization in Xenopus and Drosophila. Trends Cell Biol. 7: 485-492.

Kaminski, A., S.L. Hunt, J.G. Patton, and R.J. Jackson. 1995. Direct evidence that polypyrimidine tract binding protein (PTB) is essential for internal initiation of translation of encephal omyocarditis virus RNA. RNA 1: 924-938.

Kislauskis, E.H., Z. Li, R.H. Singer, and K.L. Taneja. 1993. Isoform-specific $3^{\prime}$-untranslated sequences sort $\alpha$-cardiac and $\beta$-cytoplasmic actin messenger RN As to different cytoplasmic compartments. J. Cell Biol. 123: 165-172.

Kislauskis, E.H., X. Zhu, and R.H. Singer. 1994. Sequences responsible for intracel lular localization of beta-actin messenger RN A al so affect cell phenotype. J. Cell Biol. 127: 441-451.

Kloc, M . and L.D. Etkin. 1995. Two distinct pathways for the local ization of RNAs at the vegetal cortex in Xenopus oocytes. Development 121: 287-297.

Kloc, M., G. Spohr, and L.D. Etkin. 1993. Translocation of repetitive RN A sequences with the germ plasm in Xenopus oocytes. Science 262: 1712-1714.
Kuznetsov, S.A., G.M. Langford, and D.G. Weiss. 1992. Actin-dependent organelle movement in squid axoplasm. Nature 356: 722-725.

Lillie, S.H. and S.S. Brown. 1992. Suppression of a myosin defect by a kinesin-related gene. Nature 356: 358-361.

Lustig, K.D., K.L. Kroll, E.E. Sun, and M.W. Kirschner. 1996. Expression cloning of a Xenopus T-related gene (Xombi) involved in mesodermal patterning and blastopore lip formation. Development 122: $4001-4012$.

Melton, D.A. 1987. Translocation of a localized maternal mRNA to the vegetal pole of Xenopus oocytes. Nature 328: 80-82.

Mosquera, L., C. Forristall, Y. Zhou, and M.L. King. 1993. A mRNA localized to the vegetal cortex of Xenopus oocytes encodes a protein with nanos-like zinc finger domain. Development 117: 377-386.

Mowry, K.L. 1996. Complex formation between stage-specific oocyte factors and a Xenopus mRN A localization el ement. Proc. Natl. Acad. Sci. 93: 14608-14613.

Mowry, K.L. and D.A. Melton. 1992. Vegetal messenger RNA localization directed by a 340-nt RN A sequence el ement in Xenopus oocytes. Science 255: 991-994.

Mueller-Pillasch, F., U. Lacher, C. Wallrapp, A. Micha, F. Zimmerhackl, H. Hameister, G. Varga, H. Friess, M. Buchler, H.G. Beger, M.R. Vila, G. Adler, and T.M. Gress. 1997. Cloning of a gene highly overexpressed in cancer coding for a novel $\mathrm{KH}$-domain containing protein. Oncogene 14: 2729-2733.

Ross, A.F., Y. Oleynikov, E.H. Kislauskis, K.L. Taneja, and R.H. Singer. 1997. Characterization of a beta-actin mRNA zipcode-binding protein. Mol. Cell Biol. 17: 2158-2165.

Schwartz, S.P. 1996. "Localization of Vgl-A maternal mRNA", Ph.D. thesis. Hebrew University, Jerusal em, Israel.

Schwartz, S.P., L. Aisenthal, Z. Elisha, F. Oberman, and J.K. Yisraeli. 1992. A 69 kDa RNA binding protein from Xenopus oocytes recognizes a common motif in two vegetally localized maternal mRN As. Proc. Natl. Acad. Sci. 89: 11895-11899.

Siomi, H., M. Choi, M.C. Siomi, R.L. N ussbaum, and G. Dreyfuss. 1994. Essential role for $\mathrm{KH}$ domains in RNA binding: Impaired RNA binding by a mutation in the $\mathrm{KH}$ domain of FMR1 that causes fragile $\mathrm{X}$ syndrome. Cell 77: 33-39.

Siomi, H. and G. Dreyfuss. 1997. RN A-binding proteins as regulators of gene expression. Curr. O pin. Genet. Dev. 7: 345-353.

St. Johnston, D. 1995. The intracellular local ization of messenger RN As. Cell 81: 161-170.

Stennard, F., G. Carnac, and J.B. Gurdon. 1996. The Xenopus T-box gene, Antipodean, encodes a vegetally localised maternal mRNA and can trigger mesoderm formation. Development 122: 4179-4188.

Sundell, C.L. and R.H. Singer. 1991. Requirement of microfilaments in sorting of actin messenger RNA. Science 253: 1275-1277.

Woehlke, G., A.K. Ruby, C.L. Hart, B. Ly, N. Hom Booher, and R.D. Vale. 1997. Microtubule interaction site of the kinesin motor. Cell 90: 207-216.

Yisraeli, J.K. and D.A. Melton. 1988. The maternal mRNA Vg1 is correctly localized following injection into Xenopus oocytes. Nature 336: 592-595.

Yisraeli, J.K., S. Sokol, and D.A. M elton. 1990. A two-step model for the localization of a maternal mRNA in Xenopus oocytes: Involvement of microtubules and microfilaments in translocation and anchoring of Vgl mRNA. Development 108: 289-298.

Zhang, J. and M.L. King. 1996. Xenopus VegT RNA is localized to the vegetal cortex during oogenesis and encodes a novel T-box transcription factor involved in mesodermal patterning. Development 122: 4119-4129.

Zhou, Y. and M.L. King. 1996a. Localization of Xcat-2 RNA, a putative germ plasm component, to the mitochondrial cl oud in Xenopus stage I oocytes. Devel opment 122: 2947-2953.

- - . 1996b. RN A transport to the vegetal cortex of Xenopus oocytes. Dev. Biol. 179: 173-183. 


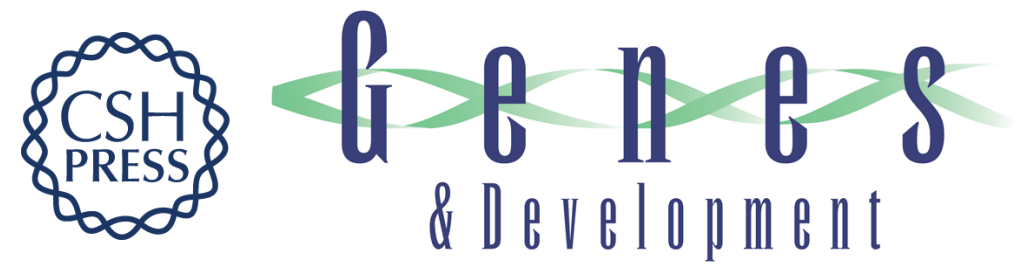

\section{RNA-binding protein conserved in both microtubule- and microfilament-based RNA localization}

Leora Havin, Anna Git, Zichrini Elisha, et al.

Genes Dev. 1998, 12:

Access the most recent version at doi:10.1101/gad.12.11.1593

References This article cites 32 articles, 20 of which can be accessed free at: http://genesdev.cshlp.org/content/12/11/1593.full.html\#ref-list-1

License

Email Alerting

Receive free email alerts when new articles cite this article - sign up in the box at the top Service right corner of the article or click here.

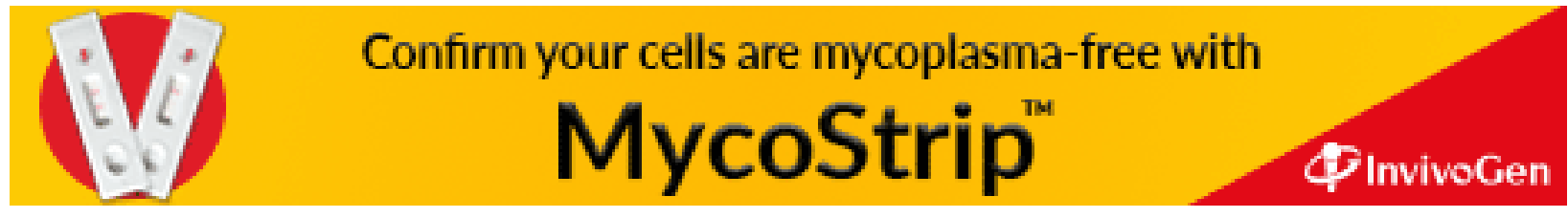

